\title{
Influence of observable and unobservable exposure on the patient's risk of acquiring influenza-like illness at hospital
}

\author{
C Payet, N Voirin*, P Vanhems, R Ecochard \\ From 3rd International Conference on Prevention and Infection Control (ICPIC 2015) \\ Geneva, Switzerland. 16-19 June 2015
}

\section{Introduction}

During outbreaks of hospital-acquired influenza-like illness (HA-ILI) healthcare workers, patients, relatives, and visitors are each source of infection for the others. Quantifying the contribution of various exposures will help improve prevention and control of HA-ILI outbreaks.

\section{Objectives}

The objective was to study the influence of observable exposure to contagious patients and HCWs and of unobservable exposure to other sources on the patient's risk of acquiring influenza-like illness at hospital.

\section{Methods}

On the basis of data from three influenza outbreaks at hospital, we used a statistical model and Bayesian inference to estimate the attributability of HA-ILI to each of: 1) exposure to recorded $v s$. unrecorded sources; 2) exposure to contagious patient $v s$. contagious healthcare workers; 3 ) exposure during observable $v s$. unobservable contagious period of the recorded sources; and, 4) the moment of exposure.

\section{Results}

Among recorded sources, 59\% (95\% credible interval: 34-83\%) of HA-ILIs of patients were associated with exposure to contagious patients and $41 \%$ (17-66\%) with exposure to contagious healthcare workers. Exposure during the unobservable contagiousness period of source patients and healthcare workers accounted for $49 \%$ (19$75 \%)$ and $82 \%$ (51-99\%) of HA-ILIs, respectively. About $80 \%$ of HA-ILIs were associated with exposure one day earlier.

\footnotetext{
Hospices Civils De Lyon, Universite Lyon, Lyon, France
}

\section{Conclusion}

Secondary cases of HA-ILI might appear as soon as the day after the detection of a primary case highlighting the explosive nature of HA-ILI spread. Unobservable transmission was the main cause of HA-ILI outbreaks suggesting that symptom-based control measures alone might not reduce transmission. The results support vaccination against influenza of patients and healthcare workers and rapid interventions to control transmission.

\section{Disclosure of interest}

None declared.

Published: 16 June 2015

\section{doi:10.1186/2047-2994-4-S1-O60}

Cite this article as: Payet et al.: Influence of observable and

unobservable exposure on the patient's risk of acquiring influenza-like

illness at hospital. Antimicrobial Resistance and Infection Control 2015

4(Suppl 1):060.

Submit your next manuscript to BioMed Central and take full advantage of:

- Convenient online submission

- Thorough peer review

- No space constraints or color figure charges

- Immediate publication on acceptance

- Inclusion in PubMed, CAS, Scopus and Google Scholar

- Research which is freely available for redistribution 